\title{
Tocopherols, Polyprenols and Steroids from Passiflora edulis and Bioactivities of its Extractives
}

\author{
Md. Abdul Aziz ${ }^{1}$, Monira Ahsan ${ }^{1}$, Choudhury Mahmood Hasan ${ }^{1}$ \\ and Mohammad Mehedi Masud ${ }^{1}$
}

\author{
${ }^{1}$ Phytochemical Research Laboratory, Department of Pharmaceutical Chemistry, Faculty of Pharmacy, \\ University of Dhaka, Dhaka-1000, Bangladesh
}

(Received: March 05, 2017; Accepted: April 10, 2017; Published (web): June 21, 2017)

\begin{abstract}
: $\beta$-tocopherol (1), $\delta$-tocopherol (2), polyprenol-12 (3), polyprenol-15 (4), stigmasterol and $\beta$-sitosterol were isolated from the yellow flavicarpa variety of leaves of Passiflora edulis. The structures of the isolated compounds were elucidated using ${ }^{1} \mathrm{H}-\mathrm{NR}$ and ${ }^{13} \mathrm{C}-\mathrm{NMR}$ spectral analysis. The organic and aqueous soluble fractions of crude methanolic extract were evaluated for the antioxidant, cytotoxic, thrombolytic and antimicrobial activities. In DPPH free radical scavenging assay, the aqueous soluble fraction displayed maximum activity having $\mathrm{IC}_{50}$ value of $139.56 \mu \mathrm{g} / \mathrm{ml}$. On the other hand, dichloromethane soluble fraction revealed maximum cytotoxic $\left(\mathrm{LC}_{50} 24.17 \mu \mathrm{g} / \mathrm{ml}\right)$ and thrombolytic $(14.49 \%$ clot lysis) activities, when compared to the respective blanks.
\end{abstract}

Key words: Passiflora edulis, chromatography, tocopherol, polyprenol, DPPH, antioxidant, thrombolysis

\section{INTRODUCTION}

Passiflora edulis Sims (Family: Passifloraceae, Bengali name: Tang Phal; English name: Passion fruit) is a vine species of passion flower that is native to Brazil, Paraguay and Northern Argentina ${ }^{1}$. Different parts of the plant have been used as medicines for many years. The leaves are reported to contain polyphenols, which act as natural antioxidant. $^{2}$ The aqueous extract of leaves has potent anti-inflammatory action. ${ }^{3}$ Several species of Passiflora have been employed widely as folk medicines because of sedative and tranquillizing activities. ${ }^{4}$ Traditionally, it has also been used as antihypertensive agent. ${ }^{5}$ It has also cholesterol and lipid lowering effects. ${ }^{6}$ Decoction of fruits of $P$. edulis inhibits metallo-proteases which are involved in the tumor invasions, metastasis and angiogenesis. ${ }^{7}$ As part of our continuing phytochemical research we studied bright yellow flavicarpa variety of $P$. edulis and herein, we report six compounds (1-6) from the methanolic extract of its leaves. The antioxidant,

Correspondence to: Mohammad Mehedi Masud Mob: +880 1758064654, +880-2-9661900 Ext. 8139;

E-mail: mehedi33@du.ac.bd

Dhaka Univ. J. Pharm. Sci. 16(1): 55-60, 2017 (June) thrombolytic, antimicrobial and other bioactivities of different fractions are also reported here.

\section{MATERIALS AND METHODS}

General experimental procedures. NMR spectra were recorded using Brucker $(400 \mathrm{MHz})$ instrument in deuterated chloroform $\left(\mathrm{CDCl}_{3}\right)$ and the $\delta$ values are reported relative to the residual nondeuterated solvent signal. Buchi Rotavapor (Germany) was used for solvent evaporation. Vacuum liquid chromatography (VLC) and gel permeation chromatography (GPC) were performed on Kieselgel 60H (mesh 70-230) and Sephadex (LH20). Analysis of the compounds were carried out over precoated thin layer chromatography plates (Silica gel $60 \mathrm{~F}_{254}$, Merck). For the visualization of the spots on TLC plates, UV light and vanillin $/ \mathrm{H}_{2} \mathrm{SO}_{4}$ reagents were used. All the other chemicals used in the research were of analytical grade.

Collection of plant sample. The leaves of yellow flavicarpa variety of Passiflora edulis Sims were collected from Barisal area, in the month of April, 2015 and it was identified in Bangladesh 
National Herbarium, where a voucher specimen (DACB number-42018) for this collection has been preserved for future reference.

Extraction and isolation. The air dried and powdered leaves $(700 \mathrm{~g})$ of $P$. edulis were soaked in 2.5 liters of methanol in an amber glass container. It was sealed by cotton plug and then kept for period of two weeks with occasional shaking and stirring. After two weeks, whole mixture was filtered off through a filter paper and the filtrate thus obtained was concentrated at $40^{\circ} \mathrm{C}$ using Buchi Rotavapor (Germany). Finally $34.17 \mathrm{~g} \quad(4.88 \%)$ of dried methanolic extract was obtained.

A portion of the crude extract $(25 \mathrm{~g})$ was then subjected to vacuum liquid chromatography (VLC) over silica gel. ${ }^{8}$ First the column was eluted using $100 \%$ petroleum then the polarity of the solvent was increased by adding dichloromethane and then ethyl acetate until it reached to $100 \%$ dichloromethane and ethyl acetate. Then the polarity of the solvent was further increased by adding methanol until it was reached to $100 \%$. A total of 29 VLC fractions were collected. After careful TLC screening VLC fractions obtained with $30 \%$ dichloromethane in petroleum ether, $50 \%$ dichloromethane in petroleum ether, $100 \%$ dichloromethane, $5 \%$ ethyl acetate in dichloromethane, $8 \%$ ethyl acetate in dichloromethane, $10 \%$ ethyl acetate in dichloromethane and $15 \%$ ethyl acetate in dichloromethane were further subjected to gel permeation chromatography (GPC) using Sephadex (LH-20) column. The Sephadex column was eluted using $20 \%$ petroleum ether in chloroform, $10 \%$ petroleum ether in chloroform and $100 \%$ chloroform. The polarity was further increased by mixing methanol with chloroform.

A total of 169 sub-fractions of the VLC fraction eluted with $15 \%$ ethyl acetate in dichloromethane were collected from the Sephadex column. The subfractions were screened by TLC and sub-fractions 27 30 were mixed together from which crystal linemess were collected by washing with $n$-hexane. The crystal were a mixture of stigmasterol and $\beta$-sitosterol. Subfractions 38-40 were mixed together and subjected to
PTLC using 2\% ethyl acetate in toluene to yield compound 2. Again, sub-fractions $42-44$ were mixed together and subjected to PTLC using 2\% ethyl acetate in toluene to yield compound $\mathbf{1}$.

VLC fraction eluted with $8 \%$ ethyl acetate in dichloromethane was subjected to the Sephadex column and a total of 33 sub-fractions were obtained. PTLC of sub-fractions 16-20 using 1\% ethyl acetate in toluene provided compound $\mathbf{3}$ and $\mathbf{4}$.

Preparation of different partitionates for biological tests. Crude methanolic extract $(5 \mathrm{~g})$ was fractionated by the modified Kupchan partitioning portocol. ${ }^{9}$ The resultant partitionates were evaporated to dryness to yield petroleum ether soluble fraction (PESF, $1.7 \mathrm{~g}$ ), dichloromethane soluble fraction (DCMSF, $0.4 \mathrm{~g}$ ), chloroform soluble fraction (CSF, $1.2 \mathrm{~g}$ ), aqueous soluble fractions (AQSF, $1.1 \mathrm{~g}$ ) and methanolic extract $(0.6 \mathrm{~g})$.

DPPH free radical scavenging assay. The antioxidant activity of different test samples was determined by evaluating the scavenging activities of the stable 1,1-diphenyl-2-picrylhydrazyl (DPPH) free radical by using standard antioxidant ascorbic acid as reference standard. ${ }^{10}$

Brine shrimp lethality bioassay. The general toxic properties of the dimethylsulfoxide (DMSO) solution of the plant extractives against Artemia salina were estimated in a $24 \mathrm{hrs}$ assay by using vincristine sulphate as positive control. ${ }^{11}$

Thrombolytic acitivity. The thrombolytic activity was assessed following the method developed by Prasad and Harbertson, ${ }^{12}$ by using streptokinase as positive control.

Antimicrobial screening. Disc diffusion method $^{13}$ was used to determine the antimicrobial activity of different partitionates of the crude extract.

Statistical analysis. For all bioassays, three replicates of each sample were used for statistical analysis and the values have been reported as mean \pm SD. 


\section{RESULT AND DISCUSSION}

Six compounds were isolated from the crude methanol extract of leaves of $P$. edulis by using repeated chromatographic separations over the silica gel. The structure of isolated compounds were elucidated as $\beta$-tocopherol (1) ${ }^{14,15}, \delta$-tocopherol (2) ${ }^{15,16}$, polyprenol-12 (3) $)^{17}$, polyprenol-15 (4) $)^{17}$, stigmasterol $^{18,19}$ and $\beta$-sitosterol ${ }^{18,19}$ by analyzing the NMR spectral data and comparing those data with published values. In some cases, co-TLC was done with the reference sample which also ensure the identity of the compounds.

$\beta$-tocopherol (Syn. (2R)-2,5,8-Trimethyl-2[(4R,8R)-(4,8,12-trimethyltridecyl)]-3,4-dihydrochromen-6-ol) (1): yellow viscous liquid and soluble in ethyl acetate and chloroform; ${ }^{1} \mathrm{H}$ NMR $(400 \mathrm{MHz}$, $\left.\mathrm{CDCl}_{3}\right): \delta 0.85$ (3H, m, Me-4'), 0.85 (3H, m, Me-8'), $0.86\left(6 \mathrm{H}, \mathrm{d}, J=6.8 \mathrm{~Hz}, \mathrm{Me}-122^{\prime}\right), 1.22(3 \mathrm{H}, \mathrm{s}, \mathrm{Me}-2)$, $1.74(1 \mathrm{H}, \mathrm{m}, \mathrm{H}-3), 1.79(1 \mathrm{H}, \mathrm{m}, \mathrm{H}-3), 2.08(3 \mathrm{H}, \mathrm{s}$, Me-5), 2.10 (3H, s, Me-8), 2.59 (2H, t, J=6.8 Hz, H4), $6.47(1 \mathrm{H}, \mathrm{s}, \mathrm{H}-7) ;{ }^{13} \mathrm{C} \mathrm{NMR}\left(100 \mathrm{MHz}, \mathrm{CDCl}_{3}\right)$ : $\delta 11.0$ (Me-5), 15.9 (Me-8), 19.8 (Me-4'8'), 20.8 (C4), 21.0 (C-2'), 22.7 (Me-12'), 23.9 (Me-2), 24.5 (C10'), 24.8 (C-6'), 28.0 (C-12'), 31.5 (C-3), 32.7 (C8'), 32.8 (C-4'), 37.3 (C-9'), 37.4 (C-7'), 37.5 (C3',5'), 39.4 (C-11'), 40.1 (C-1'), 74.5 (C-2), 115.3 (C7), 119.2 (C-5), 120.4 (C-10), 124.1 (C-8), 145.7 (C9), 146.0 (C-6).

$\delta$-tocopherol (Syn.(2R)-2,8-dimethyl-2-[(4R, 8R)-4,8,12-trimethyltridecyl\}]-6-chromanol) (2): brownish yellow liquid and soluble in ethyl acetate and chloroform; ${ }^{1} \mathrm{H}$ NMR (400 MHz, $\mathrm{CDCl}_{3}$ ): $\delta 0.85$ $\left(3 \mathrm{H}, \mathrm{m}, \mathrm{Me}-4^{\prime}\right), 0.85$ (3H, m, Me-8'), $0.86(6 \mathrm{H}, \mathrm{d}$, $\left.J=6.8, \mathrm{Me}-12^{\prime}\right), 1.23(3 \mathrm{H}, \mathrm{s}, \mathrm{Me}-2), 1.72(1 \mathrm{H}, \mathrm{m}, \mathrm{H}-$ 3), $2.11(3 \mathrm{H}, \mathrm{s}, \mathrm{Me}-8), 2.67(2 \mathrm{H}, \mathrm{t}, \mathrm{H}-4), 6.37(1 \mathrm{H}$, br. s, H-5), 6.47 (1H, br. s, H-7).

Polyprenol-12 (Syn. tri-trans poly-cis prenol-12) (3): transparent oily liquid, soluble in ethyl acetate and chloroform; ${ }^{1} \mathrm{H}$ NMR (400 MHz, $\left.\mathrm{CDCl}_{3}\right): \delta 1.59$ (12H, s, 4 trans methyls), 1.67 (24H, s, 8 cismethyls), 1.74 (3H, s, Me-3), $2.03\left(-\mathrm{CH}_{2}-4,5,8,9,12,13,16\right.$, $17,20,21,24,25,28,29,32,33,36,37,40,41,44$, 45), 4.08 ( $2 \mathrm{H}, \mathrm{d}, J=7.2 \mathrm{~Hz}, \mathrm{H}_{2}-1$ ), 5.12 (br. s, H-6, $10,14,18,22,26,30,34,38,42,46), 5.43(1 \mathrm{H}, \mathrm{b}, \mathrm{t}$,
$\mathrm{H}-2) \cdot{ }^{13} \mathrm{C}$ NMR $\left(100 \mathrm{MHz}, \mathrm{CDCl}_{3}\right): \delta 59.05(\mathrm{C}-1)$, 139.94 (C-3), 131.29 (C-47), 39.79 (C of cis-trans linkage).

Polyprenol-15 (Syn. tri-trans poly-cis prenol-15) (4): transparent oily liquid, soluble in ethyl acetate and chloroform; ${ }^{1} \mathrm{H}$ NMR (400 MHz, $\mathrm{CDCl}_{3}$ ): $\delta 1.59$ $(12 \mathrm{H}, \quad s, 4$ transmethyls $), 1.67(33 \mathrm{H}, \quad \mathrm{s}, 11$ cis methys), $1.73(3 \mathrm{H}, \mathrm{s}, \mathrm{Me}-3), 2.03\left(-\mathrm{CH}_{2}-4,5,8,9\right.$, $12,13,16,17,20,21,24,25,28,29,32,33,36,37$, $40,41,44,45,48,49,52,53,56,57), 4.08(2 \mathrm{H}, \mathrm{d}$, $J=7.2 \mathrm{~Hz}, \mathrm{H}-1$ ), 5.11 (br. s, H-6, 10, 14, 18, 22, 26, $30,34,38,42,46,50,54,58), 5.43(1 \mathrm{H}, \mathrm{b}, \mathrm{t}, J=7.2$, $\mathrm{H}-2)$.

Stigmasterol: ${ }^{1} \mathrm{H}$ NMR (400 MHz, $\mathrm{CDCl}_{3}$ ): $\delta 0.69$ (3H, s, Me-18), 0.79 (3H, d, J=6.5 Hz, H-26), 0.81 $(3 \mathrm{H}, \mathrm{t}, J=7.5 \mathrm{~Hz}, \mathrm{H}-29), 0.85(3 \mathrm{H}, \mathrm{d}, J=6.5 \mathrm{~Hz}, \mathrm{H}-$ 27), 0.99 (3H, s, Me-19), 1.016 (3H, d, $J=7.5 \mathrm{~Hz}, \mathrm{H}-$ 21), $3.51(1 \mathrm{H}, \mathrm{m}, \mathrm{H}-3), 5.01(1 \mathrm{H}, \mathrm{m}, \mathrm{H}-22), 5.13(1 \mathrm{H}$, m, H-23), 5.35 (1H, br. s, H-6).

$\beta$-sitosterol: ${ }^{1} \mathrm{H}$ NMR (400 MHz, $\mathrm{CDCl}_{3}$ ): $\delta 0.69$ $(3 \mathrm{H}, \mathrm{s}, \mathrm{Me}-18), 0.81$ (3H, d, J=6.4 Hz, H-26), 0.83 $(3 \mathrm{H}, \mathrm{d}, J=6.4 \mathrm{~Hz}, \mathrm{H}-27), 0.85(3 \mathrm{H}, \mathrm{t}, J=7.4 \mathrm{~Hz}, \mathrm{H}-$ 29), 0.916 (3H, d, J=6.4 Hz, H-21), 1.01 (3H, s, Me19), 3.51 (1H, m, H-3), 5.35 (1H, br. s, H-6).

Compound 1 was obtained as yellow viscous liquid. The ${ }^{1} \mathrm{H}$ NMR spectrum $\left(400 \mathrm{MHz}, \mathrm{CDCl}_{3}\right.$ ) of compound 1 showed the presence of three methyl signals at $\delta 1.22(3 \mathrm{H}, \mathrm{s}, \mathrm{Me}-2), 2.08(3 \mathrm{H}, \mathrm{s}, \mathrm{Me}-5)$ and $2.10(3 \mathrm{H}, \mathrm{s}, \mathrm{Me}-8)$ and two characteristic signals at $\delta 6.47(1 \mathrm{H}, \mathrm{s}, \mathrm{H}-7), \delta 2.59(2 \mathrm{H}, \mathrm{t}, \mathrm{H}-4)$ all of which indicate the presence of chromanering with three methyl substituents. The presence of methyl signals at position $\delta 0.85\left(3 \mathrm{H}, \mathrm{m}, \mathrm{Me}-4^{\prime}\right), 0.85(3 \mathrm{H}, \mathrm{m}, \mathrm{Me}-$ $\left.8^{\prime}\right)$ and $0.86\left(3 \mathrm{H}, \mathrm{m}, \mathrm{Me}-12^{\prime}\right)$ indicate that those methyl groups are in the aliphatic side chain. The ${ }^{13} \mathrm{C}$ NMR spectrum (100 MHz, $\left.\mathrm{CDCl}_{3}\right)$ of the compound 1 showed signals at position $\delta 11.0(\mathrm{Me}-5), 15.9$ (Me8), 19.8 (Me-4'8'), 20.8 (C-4), 21.0 (C-2'), 22.7 (Me12'), 23.9 (Me-2), 31.5 (C-3), 37.5 (C-3'), 40.1 (C1'),74.5 (C-2), 115.3 (C-7), 119.2 (C-5), 120.4 (C10),124.1 (C-8), 145.7 (C-9), 146.0 (C-6) which are in close agreement with the observed NMR data of $\beta$ tocopherol. ${ }^{14,15}$ 
The ${ }^{1} \mathrm{H}$ NMR spectrum of the compound 2 showed signals of two methyl groups at $\delta 1.23(3 \mathrm{H}, \mathrm{s}$, Me-2) and 2.11 (3H, s, Me-8). All the NMR signals of compound 2 matched with the compound 1 except the absence of methyl group at $\mathrm{C}-5$, instead of which it showed a signal at $\delta 6.37(1 \mathrm{H}$, br. s, H-5) which indicates the presence of chromane ring with two methyl substituents. The methyl signals at position $0.85\left(3 \mathrm{H}, \mathrm{m}, \mathrm{Me}-4^{\prime}\right)$ and $0.86\left(3 \mathrm{H}, \mathrm{m}, \mathrm{Me}-12^{\prime}\right)$ indicate that those methyl groups are in the aliphatic side chain. The NMR data of compound 2 was also compared with the reference values which confirmed that the compound $\mathbf{2}$ was $\delta$-tocopherol. ${ }^{15,16}$

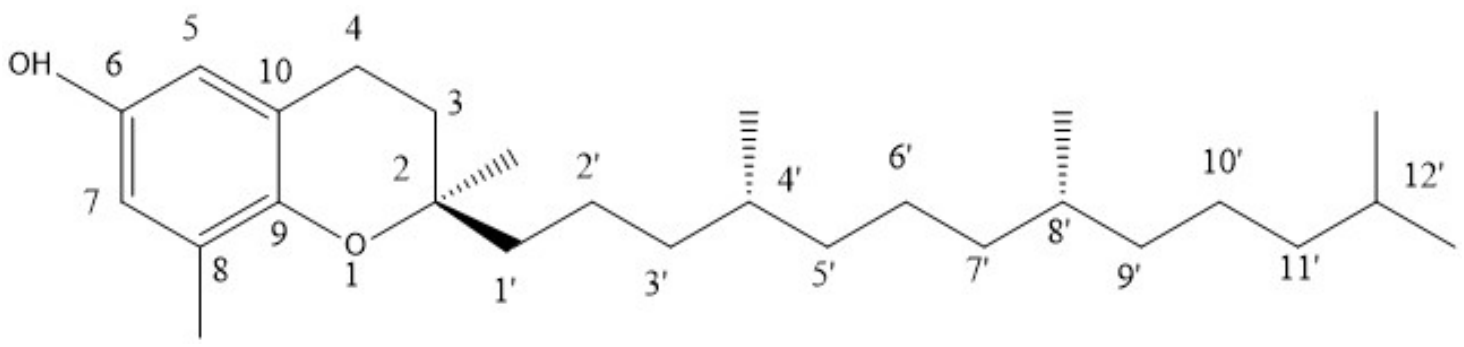

$\beta$-tocopherol (1)

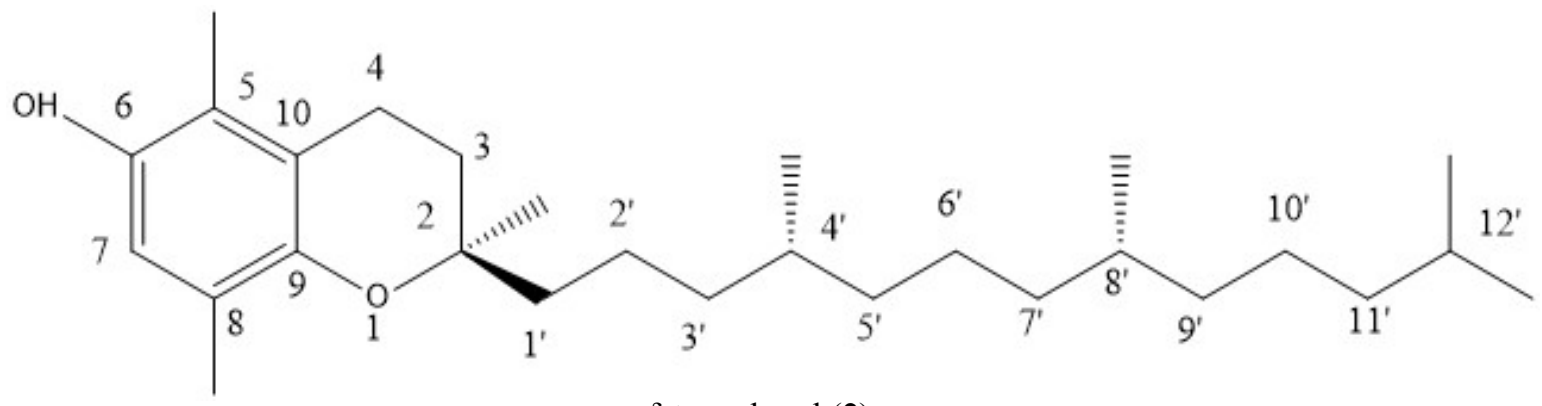

$\delta$-tocopherol (2)

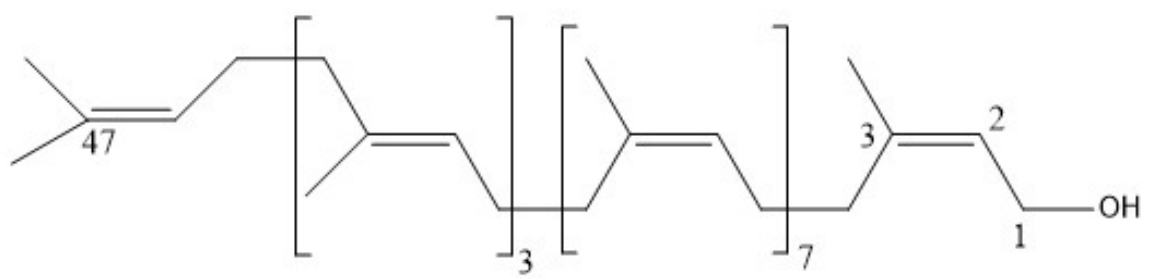

tri-transpoly-cis prenol-12 (3)

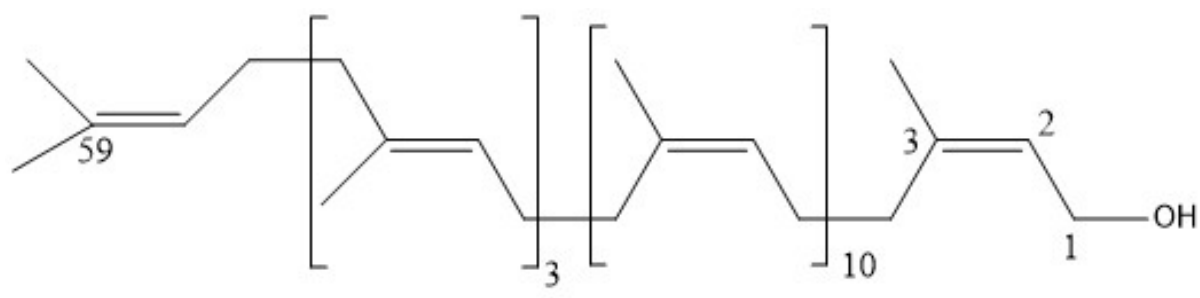

tri-transpoly-cis prenol-15 (4) 
Table 1. Free radical scavenging, cytotoxicity and thrombolytic activities of $P$. edulis.

\begin{tabular}{ccccc}
\hline Sample & $\begin{array}{c}\text { DPPH free radical scavenging } \\
\text { activity }\left(\mathrm{IC}_{50} \mu \mathrm{g} / \mathrm{ml}\right)\end{array}$ & $\begin{array}{c}\text { Cytotoxicity } \\
\left(\mathrm{LC}_{50} \mu \mathrm{g} / \mathrm{ml}\right)\end{array}$ & \% Clot lysis \\
\hline Extract & ME & $337.26 \pm 2.32$ & $188.56 \pm 1.03$ & $17.25 \pm 0.39$ \\
& PESF & $252.45 \pm 1.21$ & $92.92 \pm 0.83$ & $15.42 \pm 0.63$ \\
& DCMSF & $208.96 \pm 2.78$ & $24.17 \pm 0.22$ & $14.49 \pm 0.53$ \\
& CSF & $157.14 \pm 1.53$ & $39.60 \pm 0.37$ & $15.38 \pm 0.45$ \\
Standard & AQSF & $139.56 \pm 1.67$ & $74.84 \pm 0.87$ & $16.95 \pm 0.56$ \\
& Ascorbic acid & $37.22 \pm 0.76$ & - & - \\
& VS & - & $0.404 \pm 0.03$ & $33.60 \pm 1.09$ \\
\hline
\end{tabular}

$\mathrm{ME}=$ Methanolic extract, $\mathrm{PESF}=$ Petroleum ether soluble fraction, $\mathrm{DCMSF}=$ Dichloromethane soluble fraction, $\mathrm{CSF}=\mathrm{Chloroform}$ soluble fraction, $\mathrm{AQSF}=$ Aqueous soluble fraction, VS= Vincristine sulphate, $\mathrm{SK}=$ Streptokinase (Positive control); Water (Negative control for thrombolytic activity)

The ${ }^{1} \mathrm{H}$ NMR spectrum of the compound 3 and $\mathbf{4}$ showed signals at $\delta 5.43(1 \mathrm{H}$, br. $\mathrm{t}, J=7.2, \mathrm{H}-2)$ and $4.08(2 \mathrm{H}, \mathrm{d}, J=7.2, \mathrm{H}-1)$. The signal at $\delta 1.67$ was the characteristic peak of cis-methyls and $\delta 1.59$ was assigned to all trans-methyls. On the other hand, methyl at $\mathrm{C}-3$ gave signal at $\delta 1.74$. The signal at $\delta$ 2.03 indicates the methylene hydrogen. ${ }^{13} \mathrm{C}$ NMR spectrum $\left(100 \mathrm{MHz}, \mathrm{CDCl}_{3}\right)$ showed the signal at $\delta$ 40.0 which is the cis-trans-linkange carbon. All the signals are close agreement with the ${ }^{1} \mathrm{H}$ NMR and ${ }^{13} \mathrm{C}$ NMR signals of polyprenols which were also confirmed with the reference value. ${ }^{17}$ Both compounds had same signals but they were different only in integration value which ensured that the compound $\mathbf{3}$ and $\mathbf{4}$ was identified as tri-transpoly-cis prenol-12 and di-transpoly-cis prenol-15 respectively.

Stigmasterol and $\beta$-sitosterol were identified after comparing their ${ }^{1} \mathrm{H}$ NMR spectral data with the reference values. ${ }^{18,19}$

Bioactivities of the crude extract and its different fractions. In case of DPPH free radical scavenging assay, the aqueous soluble fraction of leaves of $P$. edulis showed moderate free radical scavenging activity having $\mathrm{IC}_{50}$ value of $139.56 \pm 1.67 \mu \mathrm{g} / \mathrm{ml}$, while the standard ascorbic acid showed $\mathrm{IC}_{50}$ value of $37.22 \pm 0.76 \mu \mathrm{g} / \mathrm{ml}$ (Table 1).

In the brine shrimp lethality test, the dichloromethane soluble fraction displayed the maximum cytotoxic effect with $\mathrm{LC}_{50}$ value of $24.17 \pm$ 0.22 as compared to $0.404 \pm 0.03$ for vincristine sulphate. On the other hand, the dichloromethane soluble fraction of the crude methanol extract showed the highest thrombolytic activity having the percentage clot lysis of $14.49 \pm 0.53$ where standard streptokinase showed $33.60 \pm 1.09 \%$ of clot lysis. All the partitionates and methanolic extract were assayed for the antimicrobial activities against different grampositive and gram-negative bacteria taking antibiotic vancomycin as a standard. None of the samples showed any antimicrobial properties where the standard vancomycin displayed significant antimicrobial activity.

\section{CONCLUSION}

The methanolic extract of the leaves of Passiflora edulis was investigated for isolation of the secondary metabolites. Successive chromatographic separation and purification yielded a total of six compounds namely $\beta$-tocopherol, $\delta$-tocopherol, polyprenol-12, polyprenol-15, stigmasterol and $\beta$ sitosterol. In free radical scavenging activity assay, aqueous soluble fraction of $P$. edulis showed the maximum free radical scanvenging activity with $\mathrm{IC}_{50}$ value of $139.56 \mu \mathrm{g} / \mathrm{ml}$. However, the dichloromethane soluble fraction (DCMSF) showed maximum thrombolytic and cytotoxic activities. Our findings justify the traditional uses of the plant. Therefore, considering the isolated compounds and the potential bioactivities of different fractions of the crude extract, this plant can further be studied to find 
out the unrevealed scientific findings which might be helpful in medicinal chemistry.

\section{REFERENCES}

1. Morton, J.F. 1987. Passionfruit, In: Fruits of warm climates. New Crop, Center for New Crops \& Plant Products, Department of Horticulture and Landscape Architecture at Purdue University, W. Lafayette, IN, USA, 320-328.

2. Rudnicki, M., Oliveira, M.R., Pereira, T.V.,Reginatto, F.H., Pizzol, F.D. and Moreira, J.C.F. 2007. Antioxidant and antiglycation properties of Passiflora alata and Passiflora edulis extracts. Food Chem. 100, 719-724.

3. Bernica, J.P., Montanher, A.B., Zucolotto, S.M., Schenkel, E.P. and Frode, T.S. 2007. Evaluation of anti-inflammatory efficacy of Passiflora edulis. Food Chemistry 104, 10971105.

4. Barbosa, P.R., Valvassori, S.S., Bordignon, C.L.J., Kappel, V.D., Martins, M.R., Gavioli, E.C., Quevedo, J. and Reginatto, F.H. 2008. The aqueous extracts of Passiflora alata and Passiflora edulis reduce anxiety-related behaviors without affecting memory process in rats. J. Med. Food.. 11, 282-288.

5. Konta, E.M., Almeida, M.R., Amaral, C.L., Darin, J.D., Rosso, V.V., Mercadante A.Z., Antunes, L.M. and Bianchi, M.L. 2014. Evaluation of the antihypertensive properties of yellow passion fruit pulp in spontaneously hypertensive rats. Phytother Res. 28, 28-32.

6. Chau, C.F. and Huang, Y.L. 2005. Effects of the insoluble fiber derived from Passifloraedulis seed on plasma and hepatic lipids and fecal output. Mol. Nutr. Food Res. 49, 786790 .

7. Puricelli, L., Aicab, I.D., Sartorb, L., Garbisab, S. and Caniato, R. 2003. Preliminary evaluation of inhibition of matrix-metalloprotease MMP-2 and MMP-9 by Passiflora edulis and $P$. foetida aqueous extracts. Fitoterapia 74, 302304.

8. Pelletier, S.W., Chokshi, H.P. and Desai, H.K. 1986. Separation of diterpenoid alkaloid mixtures using vacuum liquid chromatography. J. Nat. Prod. 49, 892.

9. Vanwagenen, B.C., Larsen, R., Cardellina, J.H., Randazzo, D., Lidert, Z.C. and Swithenbank, C. 1993. Ulosantoin, a potent insecticide from the sponge Ulosaruetzleri. J. Org. Chem. 58, 335-337.
10. Brand-Williams, W., Cuvelier, M.E. and Berset, C. 1995. Use of a free radical method to evaluate antioxidant activity. Lebensm. Wiss. Technol. 28, 25-30.

11. Meyer, B.N., Ferringni, N.R., Puam, J.E., Lacobsen, L.B., Nichols, D.E. and McLaughlin, J.L. 1982. Brine shrimp: a convenient general bioassay for active constituents. Planta Med. 45, 31-32.

12. Prasad, S., Kashap, R.S., Deopujari, J.Y., Purohit, H.J., Taori, G.M. and Daginawala, H.F. 2007. Effect of Fagonia Arabica on in vitro thombolysis. BMC Complement. Alernat. Med. 7, 36.

13. Bauer, A.W., Kirby, W.M.M., Sheriess, J.C. and Turck, M. 1966. Antibiotic susceptibility testing by standardized single method. Am. J. Clin. Pathol. 45, 493-496.

14. Ayres, M.C.C., Chaves, M.H., Rinaldo, D., Vilegas, W. and Vieira, G.M. 2009. Chemical constituents and antioxidant activity from leaves extracts of Terminalia fagifolia Mart. Et Zucc. Qumica Nova, SciELO. 32, 6.

15. Baker, J.K. and Myers, C.W. 1991. One-dimensional and two-dimensional ${ }^{1} \mathrm{H}$ - and ${ }^{13} \mathrm{C}$-nuclear magnetic resonance (NMR) analysis of vitamin E raw materials or analytical reference standards. Pharm. Res. 8, 763-770.

16. Mazzini, F., Alpi, E., Salvadori, P. and Netscher, T. 2003. First Synthesis of $\left(8-{ }^{2} \mathrm{H}_{3}\right)-($ all-rac $)-\delta$-Tocopherol. Eur. $J$. Org. Chem. 2840-2844.

17. Ibata, K., Mizuno, M., Takigawa, T. and Tanaka, Y. 1983. Long-chain betulaprenol-type polyprenols from the leaves of Ginkgo biloba. Biochem. J. 213, 305-311.

18. Pateh, U.U., Haruna, A.K., Garba, M., Iliya, I., Sule, I.M., Abubakar, M.S. and Ambi A.A. 2009. Isolation of stigmasterol, $\beta$-sitosterol and 2-hydroxyhexadecanoic acid methyl ester from the rhizomes of Stylochiton Lancifolius Pyer and Kotchy (Aeaceae). Nigerian J. Pharm. Sci., 7, 1925.

19. Habib, M.R., Nikkon, F., Rahman, M.E. and Karim, M.R. 2007. Isolation of stigmasteroland $\beta$-sitosterol from methanolic extract of root bark of Calotropis gigantean (Linn). Pak. J. Bio. Sci. 10, 4174-4176. 